\title{
Substrates for biofilter in recirculating system in Nile tilapia larviculture production
}

\section{Substratos para biofiltros em sistemas de recirculação na larvicultura de tilápia do Nilo}

\author{
PEDREIRA, Marcelo Mattos ${ }^{1}$; TESSITORE, Antônio Jessey de Abreu ${ }^{2}$; PIRES, Aldrin \\ Vieira $^{1}$; SILVA, Martinho de Almeida ${ }^{1}$; SCHORER, Marianne ${ }^{1}$
}

\author{
${ }^{1}$ Universidade Federal dos Vales do Jequitinhonha e Mucuri, Departamento de Zootecnia, Diamantina, \\ Minas Gerais, Brasil. \\ ${ }^{2}$ Companhia de Desenvolvimento dos Vales do São Francisco e Parnaíba, Morada Nova de Minas, Minas \\ Gerais, Brasil. \\ *Endereço para correspondência: marcelomattospedreira@gmail.com
}

\section{SUMMARY}

Recirculating water system (RAS), provide to reduce water usage and to improve the quality by nutrient recycling, so biofilters are used to reduce ammonia concentrations by oxidation to nitrate, by nitrifying-bacteria. Biological filters have been utilized to maintain acceptable water parameters to larvae and juveniles, by decreasing ammonia concentrations. The objective of this experiment was to evaluate different substrates for aquarium biofilter on performance of Nile tilapia (Oreochromis niloticus) larvae, and water quality. One-thousand-two-hundred Nile tilapia larvae (initial length $=11.6 \pm 0.82 \mathrm{~mm}$; body weight $(\mathrm{BW})$ $=189.0 \pm 0.44 \mathrm{mg}$ ) were randomly allotted into one of twenty 6-L aquariums (60 larvae aquarium ${ }^{-1}$ ) with five different biofilter (4 aquariums each biofilter): (1) control, no substrate; (2) seashell-and granitic crushed stone-substrate; (3) granitic crushed stone substrate; (4) quartz gravel substrate; and (5) porcelain-substrate. The conductivity, turbidity, $\mathrm{pH}$, nitrate, nitrite and ammonia values indicate that seashell and granitic crushed-stone, and porcelainsubstrates had greater process of biofiltration effectiveness. Water oxygen did not differ among treatments, with all levels within the benchmark for the tilapia larvae. Fishes reared in aquarium with quartz gravel-and porcelain substrate fishes had greater $\mathrm{BW}$, total and standard length compared with its from other substrates. Porcelain-substrate biofilter is indicated for tilapia larviculture due to improved weight and length and water quality.

Keywords: biofiltration, limnological parameters, nitrification, water quality, RAS

\section{RESUMO}

Sistemas de recirculação de água (RAS) reduzem o uso de água e melhoram sua qualidade com a reciclagem de nutrientes, sendo os biofiltros usados para reduzir a concentração de amônia por oxidação a nitrato, por bactérias nitrificantes. Os filtros biológicos têm sido utilizados para manter os parâmetros da água aceitáveis para larvas e juvenis, diminuindo a concentração de amônia. $\mathrm{O}$ objetivo do experimento foi avaliar diferentes tipos de substratos para biofiltro no aquário sobre $\mathrm{o}$ desempenho de larvas de tilápia do Nilo, Oreochromis niloticus, e qualidade da água. Foram utilizadas 1.200 larvas de tilápia do Nilo (comprimento inicial $=11,58 \pm 0,82 \mathrm{~mm}$; peso $=$ $189,00 \pm 44,0 \mathrm{mg})$ foram randomicamente distribuídos em vinte aquários contendo $6 \mathrm{~L}(60$ larvas aquário $^{-1}$ ) com cinco biofiltros diferentes (4 aquários cada): (1) controle, sem substrato; (2) brita granítica e concha; (3) brita granítica; (4) cascalho de quartzo e (5) porcelana. Os valores de condutividade, turbidez, $\mathrm{pH}$, nitrato, nitrito e amônia indicam que os biofiltros compostos por brita e concha e por porcelana apresentaram a melhor eficiência do processo de biofiltração. O oxigênio dissolvido na água não diferiu entre os tratamentos, sendo os níveis adequados para a espécie. Peixes cultivados em aquários com biofiltros com porcelana e cascalho no substrato, apresentaram maior peso e comprimentos total e padrão que nos demais substratos. Indica-se o uso de biofiltro composto de porcelana para a larvicultura de tilápia por proporcionar maior peso e comprimento e melhores parâmetros limnológicos.

Palavras-chave: biofiltração, parâmetros limnológicos, nitrificação, qualidade da água, RAS 
Rev. Bras. Saúde Prod. Anim., Salvador, v.17, n.3, p.553-560 jul./set., $2016 \quad \underline{\text { http://www.rbspa.ufba.br }}$

\section{INTRODUCTION}

The control of water physical-chemical parameters is important for fish production. Nile tilapia, is a fish capable to tolerate different degrees of hypoxia, starvation, overcrowding (EL-KHALDI, 2010) and other stress conditions, which can reduce performance (BISWAS et al., 2002; EL-KHALDI, 2010). Poor water quality may adversely affect growth performance. Nitrogen excess (e.g., greater ammonia, nitrite and nitrate levels) directly affects fish performance, and mortality can occur in a relatively narrow range of ammonia concentrations (KÜÇÜK, 2014).

Biofilters have been utilized to maintain acceptable water parameters to larvae and juveniles, by decreasing ammonia concentrations (OLIVEIRA et al., 2009; PEDREIRA et al., 2014), in recirculating systems aquaculture by the effective action of bacterial biofilm promoting nitrifying (CAHILL et al., 2010). Therefore, recirculating water system (RAS), provide to reduce water usage and to improve waste management and nutrient recycling (MARTINS et al., 2010).

The nitrification efficiency can vary according to type of substrate (HOROWITZ \& HOROWITZ 2000; CHEN et al., 2006; PEDREIRA et al., 2009), concentration of dissolved oxygen, temperature, $\mathrm{pH}$, alkalinity, turbulence, salinity (CHEN et al., 2006), specific surface area of substrate, and uniformity of water flow into of the biofilter (LEKANG \& KLEPPE, 2000). Though there is a few experiments comparing substrates in biofilters in the cultivation of Nile tilapia (DUARTE et al., 2013).

The use of different substrates in biofilters have task of verifying the best material to filter and purify the water used for fish production. Granitic crushed stone is by far the most used material as the ideal filler for the support media of fixed bed reactors, but the experimental use of other materials becomes attractive since granitic crushed stone is highly dense and rather costly (FIA et al., 2010). quartz gravel is also widely used (KUBITZA, 2006), and has a capability to remove the phosphorus in the system (TANG et al., 2009). Therefore, the use of substrates commonly used in recirculating water systems, the consortium substrates, and the use of new materials promove the denitrification bacteria and reduce system costs.

Therefore, the objective was to evaluate the substrate of seashell-and granitic crushed stone, granitic crushed stone, quartz gravel, and porcelain used in biofilter in aquariums, and verify Nile tilapia larvae performance and water quality.

\section{MATERIAL AND METHODS}

The experiment was conducted at the Universidade Federal dos Vales do Jequitinhonha and Mucuri (UFVJM), Laboratory of Aquatic Ecology and Aquaculture, in Diamantina, MG. Onethousand-two-hundred Nile tilapia larvae (initial length $=11.6 \pm 0.82 \mathrm{~mm}$; body weight $(\mathrm{BW})=189.0 \pm 0.44 \mathrm{mg}$ ) were randomly allotted into one of twenty $6 \mathrm{~L}$ aquariums (60 larvae aquarium $\left.{ }^{-1}\right)$ with five different biofilters ( $\mathrm{n}=4$ aquariums each biofilter): (1) control, no substrate; (2) seashell and granitic crushed stone substrate $(30 \%$ seashell and $70 \%$ granitic crushed stone; average diameter = $21.5 \mathrm{~mm}$ and $15.8 \mathrm{~mm}$, respectively); (3) granitic crushed stone substrate (average diameter $=18.0 \mathrm{~mm}$ ); (4) quartz gravel substrate (average diameter $=17.0 \mathrm{~mm}-$ 
coarse gravel); and (5) porcelain substrate (average diameter $=7.5 \mathrm{~mm}$ ). Aquariums had constant aeration, temperature of $28.0 \pm 1.20^{\circ} \mathrm{C}$, and luminosity of 403.3 lux \pm 29.66 from natural photoperiod.

Substrates were placed in plastic bottles (height $=13.4 \mathrm{~cm}$; diameter $=6.3 \mathrm{~cm}$; and water capacity $=0.40 \mathrm{~L}$ ). APVC pipe (diameter $=20.0 \mathrm{~mm}$; and height $=$ $14.0 \mathrm{~cm})$ was placed vertically in the middle of the substrate for aeration purposes, providing a water flow of $60 \mathrm{~mL} \mathrm{~min}^{-1}$. All water passed through the biofilter approximately 22 times a day. A 1-mm shade net was placed on the top of the biofilter in order to prevent fish entering, trapping and death.

Substrates were matured prior to placing into plastic bottles for 30 days to permit attachment of nitrifying bacteria, as proposed by Pedreira et al. (2009) and Carrera et al. (2013). Substrates were kept in a single 500L polyethylene box for each substrate, under strong aeration. For maturation and establishment of nitrifying bacteria, $80 \mathrm{~g}$ of artificial diet were added containing $55 \%$ crude protein (CP) twice a week.

Larvae were fed a commercial diet $(\mathrm{CP}=$ $550 \mathrm{~g} \mathrm{~kg}^{-1}$, minimum; maximum humidity $=10 \mathrm{~g} \mathrm{~kg}^{-1}$; ether extract at least $4 \mathrm{~g} \mathrm{~kg}^{-1}$; crude fiber $=6 \mathrm{~g} \mathrm{~kg}^{-1}$ maximum; ash $=18 \mathrm{~g} \mathrm{~kg}^{-1}$ maximum; calcium $=5.0 \mathrm{~g}$ $\mathrm{kg}^{-1}$ maximum; phosphorus, less than $1.5 \mathrm{~g} \mathrm{~kg}^{-1}$ ) twice daily (9:00 and 17:00 h) at $10 \%$ body weight (BW), corrected every 5 days.

Limnological variables were measured during fifteen days, always in the morning sat 9:00. Dissolved oxygen was measured using a handheld oximeter (model YSI 55, YSI Inc., Yellow Springs, OH, USA); conductivity was measured using a waterproof conductivity meter (model HI 9033, Hanna Instruments, Woonsocket, RI,
USA); and $\mathrm{pH}$ was measured using a digital $\mathrm{pH}$-meter (model Q400HM, Quimis Aparelhos Científicos, Diadema, SP, Brazil). Concentrations of ammonia, nitrite and nitrate were determined according to methodology described by APHA (2012). Temperature was recorded daily. Water was replaced daily at $10 \%$ of total aquarium volume.

Larvae survival, BW, and total and standard lengths were measured at the end of the experiment. Body weight was measured using an analytical scale. Larvae length was measured using a $0.02 \mathrm{~mm}$ accuracy caliper.

Analysis for larvae BW, total and standard length, survival, and limnological variable were achieved by ANOVA for a completely randomized design using the GLM procedures of SAS (SAS, 1998). Means were separated for comparison by Tukey's Studentized Test. Significance was set at $\mathrm{P}<0.05$.

\section{RESULTS AND DISCUSSION}

The water quality parameters (Table 1) are adequate for growing fish and they are similar to the values reported by for Nile tilapia (PAIVA et al., 2008). The water conductivity in tanks using biological shell plus granitic crushed stone was similar to granitic crushed stone treatment $(\mathrm{P} \geq 0.05)$ and greater than other substrates $(\mathrm{P}<0.05)$. The water conductivity of granitic crushed stone treatment was greater than porcelain and control treatment (without substrate) $(\mathrm{P}<0.05)$, but did not differ from the quartz gravel substrate $(\mathrm{P} \geq 0.05)$. No difference was observed between biofilter with quartz gravel, porcelain and the control (no substrate) $(\mathrm{P} \geq 0.05)$. 
Table 1. Limnological parameters of tanks on Nile tilapia larvae submitted to the biofilters with different substrates during 15 days

\begin{tabular}{|c|c|c|c|c|}
\hline Substrate & $\begin{array}{l}\text { Conductivity } \\
\left(\mu \mathrm{S} \mathrm{cm}^{-1}\right)\end{array}$ & $\begin{array}{l}\text { Turbity } \\
\text { (UNT) }\end{array}$ & $\mathrm{pH}$ & $\begin{array}{c}\text { Dissolved } \\
\text { oxigen }\left(\mathrm{mg} \mathrm{L}^{-1}\right)\end{array}$ \\
\hline No substrate (control) & $73.30 \pm 0.11^{\mathrm{c}}$ & $7.32 \pm 0.72^{\mathrm{a}}$ & $7.0 \pm 0.04^{\mathrm{a}}$ & $6.05 \pm 0.16^{\mathrm{a}}$ \\
\hline $\begin{array}{l}\text { Sea shell and granitic } \\
\text { crushed stone }\end{array}$ & $222.50 \pm 25.14^{\mathrm{a}}$ & $4.49 \pm 0.78^{b}$ & $7.09 \pm 0.04^{\mathrm{a}}$ & $6.36 \pm 0.41^{\mathrm{a}}$ \\
\hline Granitic crushed stone & $182.82 \pm 7.76^{\mathrm{ab}}$ & $3.53 \pm 0.37^{\mathrm{b}}$ & $7.06 \pm 0.37^{\mathrm{a}}$ & $6.45 \pm 0.56^{\mathrm{a}}$ \\
\hline Quartz gravel & $128.83 \pm 10,08^{\mathrm{bc}}$ & $2.75 \pm 0,42^{b}$ & $6.74 \pm 0.04^{b}$ & $6.44 \pm 0.46^{\mathrm{a}}$ \\
\hline Porcelain & $86.77 \pm 4.59^{\mathrm{c}}$ & $3.51 \pm 0.49^{\mathrm{b}}$ & $6.75 \pm 0.03^{\mathrm{b}}$ & $6.01 \pm 0.70^{\mathrm{a}}$ \\
\hline & Nitrate $\left(\mathrm{ml} \mathrm{L}^{-1}\right)$ & \multicolumn{2}{|c|}{ Nitrite $\left(\mathrm{ml} \mathrm{L}^{-1}\right) \quad \mathrm{Ar}$} & nonium $\left(\mathrm{ml} \mathrm{L}^{-1}\right)$ \\
\hline No substrate (control) & $0.19 \pm 0.03^{\mathrm{c}}$ & \multicolumn{2}{|c|}{$0.03 \pm 0.01^{\mathrm{b}}$} & $0.44 \pm 0.05^{\mathrm{a}}$ \\
\hline $\begin{array}{l}\text { Sea shell plus granitic } \\
\text { crushed stone }\end{array}$ & $0.75 \pm 0.10^{\mathrm{a}}$ & \multicolumn{2}{|c|}{$0.03 \pm 0.03^{\mathrm{b}}$} & $0.05 \pm 0.02^{\mathrm{c}}$ \\
\hline Granitic crushed stone & $0.23 \pm 0.03^{\mathrm{c}}$ & \multicolumn{2}{|c|}{$0.05 \pm 0.01^{\mathrm{a}}$} & $0.30 \pm 0.02^{\mathrm{ab}}$ \\
\hline Quartz gravel & $0.26 \pm 0.03^{\mathrm{bc}}$ & \multicolumn{2}{|c|}{$0.05 \pm 0.01^{\mathrm{a}}$} & $0.14 \pm 0.04^{\mathrm{bc}}$ \\
\hline Porcelain & $0.61 \pm 0.15^{\mathrm{ab}}$ & \multicolumn{2}{|c|}{$0.02 \pm 0.02^{\mathrm{b}}$} & $0.08 \pm 0.03^{\mathrm{c}}$ \\
\hline
\end{tabular}

Means in the same column followed by different letters differ by Tukey test $(\mathrm{P}<0.05)$.

The shell plus granitic crushed stone substrate provided a high conductivity of the water due to its limestone composition. The high conductivity due to compounds in biofilter with shell has been reported by (PEDREIRA \& RIBEIRO, 2008; DUARTE et al., 2013), and similar results of water conductivity were reported by Pedreira et al. (2009) in comparing the efficiency of biofilter using the same substrates of this experiment.

The water turbidity of the control (no substrate) differed from all other treatment $(\mathrm{P}<0.05) \quad$ because the substrates trap water particles and significantly reduce level of water turbidity. The use of substrates in biofilter decreases the water turbidity to around $60 \%$, when compared to control treatment. Lefebvre et al. (2000) observed a reduction of $56 \%$ on the turbidity of a fish farming waster, after filtration with shells. In the culture lab of red tilapia, Cavalcante Junior (2005) verified a reduction of $85.5 \%$ in the turbidity using a process of water filtration.
The $\mathrm{pH}$ of water of biofilter with seashell plus granitic crushed stone, granitic crushed stone and no substrate were higher than the water $\mathrm{pH}$ of porcelain and quartz gravel substrates $(\mathrm{P}<0.05)$, which are similar to each other $(\mathrm{P} \geq 0.05)$. The high $\mathrm{pH}$ in water of the biofilter with shell plus crushed stone can be explained by the presence of seashell calcareous.

The seashell increases the conductivity, pH (DUARTE et al., 2013) and alkalinity of the water (FRITZSONS et al., 2009), forming a buffer effect, and stabilizing the farming system. Similar result was found by Pedreira et al. (2009) using seashell plus crushed stone into external and internal biofilter, in comparison to gravel and no substrate filter

No differences among subtracts were found for water oxygen concentration $(\mathrm{P} \geq 0.05)$, and the level of oxygen were appropriate for the species studied according Duarte et al. (2013).

In general Seashell plus granitic crushed stone and porcelain provided better nitrification because these substrates 
have higher nitrate concentrations and lower concentrations of ammonia and nitrite. The nitrate levels in water of seashell plus granitic crushed stone substrate biofilter tanks were similar to the biofilter with porcelain $(\mathrm{P} \geq 0.05)$ and greater than others biofilter substrates $(\mathrm{P}<0.05)$, and has an efficient nitrification. The nitrate levels of biofilter with granitic crushed stone, quartz gravel and control (no substrate) were similar $(\mathrm{P} \geq 0.05)$.

Despite the low concentration of nitrates found in the control biofilter (without substrate), it was similar to that observed for granitic crushed stone and quartz gravel substrates $(\mathrm{P} \geq 0.05)$, suggesting that part of the ammonium ion was converted into nitrate in the column water. This result is corroborated by other studies (PEDREIRA et al., 2009).

The nitrate concentrations observed in the present experiment can be indicated the studied species, since similar results were also observed by Duarte et al. (2013) in the cultivation of tilapia. The low nitrate concentrations should be maintained because high levels typically result in algal blooms and over time can result in a lowering of $\mathrm{pH}$ (WATSON \& HILL, 2006 ).

The nitrite of biofilter with quartz gravel and granitic crushed stone substrates were higher than other treatments $(\mathrm{P}<0.05)$. No differences in nitrate were observed for biofilter with porcelain, seashell plus granitic crushed stone and control (no substrate) $(\mathrm{P} \geq 0.05)$ and the nitrite was within the range observed for Nile tilapia (DUARTE et al., 2013).

The lowest concentrations of nitrite for the biofilter with porcelain and seashell plus granitic crushed stone evidence the efficient functioning and proper acclimation of the biofilter that depends on the initial conditions of the trial (SHEINTUCH et al., 1995), and also demonstrating the role of bacteria in maintaining the water for intensive aquaculture (HOROWITZ \& HOROWITZ, 2000).

The ammonia concentration in the control treatment (no substrate) was similar to granitic crushed stone substrate $(\mathrm{P} \geq 0.05)$ but higher than the others treatments $(\mathrm{P}<0.05)$. The biofilter with granitic crushed stone did not differ of the biofilter with quartz gravel $(\mathrm{P} \geq 0.05)$, but had ammonia concentrations higher than those with porcelain and seashell and granitic crushed stone $(\mathrm{P}<0.05)$.

Comparing systems without and with biofilter contained seashell plus crushed stone, Pedreira et al. (2009) and Duarte et al. (2013) reported higher concentrations of ammonia in tanks without biofilter. Similar result comparing ammonia concentrations of seashell and porcelain used in biofilter was observed by Silva et al. (2010).

The efficiency of the nitrification process of treatments with seashell plus granitic crushed stone and porcelain may be due to the high specific surface of the substrate, which according to Horowitz \& Horowitz (2000) has a positive correlation with the number of nitrifying bacteria colony. Seashell plus crushed stone yet have the presence of calcium carbonate that can improve nitrification efficiency compared to treatment without substrate (PEDREIRA et al., 2009; DUARTE et al., 2013). The efficiency of substrates in the nitrification process of this trial resulted of the reduction in the concentration of ammonia in the water, a fact corroborated by Davidson \& Summerfel (2008). These results are important because they point out for the efficiency of biological filtration in maintains total ammonia nitrogen (TAN) and nitrite, at levels near zero (WATSON \& HILL, 2006). 
Rev. Bras. Saúde Prod. Anim., Salvador, v.17, n.3, p.553-560 jul./set., $2016 \quad \underline{\text { http://www.rbspa.ufba.br }}$ ISSN 15199940

Performance parameters: survival, total length, standard length and body weight are shown in Table 2. No differences among treatments were observed for fish survival $(\mathrm{P} \geq 0.05)$. Similar results were observed by Pedreira et al. (2009) in studying various types of substrates for biofilter.

Table 2. Performance of Nile tilapia larvae submitted to the biofilters with different substrates during 15 days

\begin{tabular}{lcccc}
\hline \multirow{2}{*}{ Substrate } & Survival & Total lenght & Standard lenght & Body weight \\
\cline { 2 - 5 } & $(\%)$ & $(\mathrm{mm})$ & $(\mathrm{mm})$ & $(\mathrm{mg})$ \\
\hline No substrate (control) & $55.83 \pm 22.5^{\mathrm{a}}$ & $15.41 \pm 0.5^{\mathrm{b}}$ & $12.10 \pm 2.0^{\mathrm{b}}$ & $490.0 \pm 30,5^{\mathrm{b}}$ \\
Sea shell and granitic & $75.83 \pm 25.5^{\mathrm{a}}$ & $14.86 \pm 0.6^{\mathrm{b}}$ & $11.84 \pm 2.1^{\mathrm{b}}$ & $520.0 \pm 28.0^{\mathrm{b}}$ \\
crushed stone & $59.58 \pm 25.5^{\mathrm{a}}$ & $15.39 \pm 0.62^{\mathrm{b}}$ & $12.07 \pm 1.2^{\mathrm{b}}$ & $554.0 \pm 22.5^{\mathrm{b}}$ \\
Granitic crushed stone & $71.25 \pm 20.4^{\mathrm{a}}$ & $16.84 \pm 0.36^{\mathrm{a}}$ & $13.26 \pm 1,1^{\mathrm{a}}$ & $739.0 \pm 50.2^{\mathrm{a}}$ \\
Quartz gravel & $73.75 \pm 22.5^{\mathrm{a}}$ & $17.72 \pm 0.6^{\mathrm{a}}$ & $14.14 \pm 1.9^{\mathrm{a}}$ & $879.0 \pm 0.48^{\mathrm{a}}$ \\
Porcelain &
\end{tabular}

Means in the same column followed by different letters differ by Tukey test $(\mathrm{P}<0.05)$.

Total and standard length, and body weight of Tilapia were similar for porcelain and quartz gravel biofilter substrate $(P \geq 0.05)$, but higher than other treatments $(\mathrm{P}<0.05)$. The biofilter with quartz gravel, seashell plus granitic crushed stone and control (no substrate) did not differ $(\mathrm{P} \geq 0.05)$. The difference for total and standard lengths and body weight observed in some treatments of this trial probably resulted of the welfare according to Duarte et al. (2013). In studies with juveniles tilapia the growth, length and body weight, was not affected by different substrates (AL-HAFEDH et al., 2003). These results can be explained by the similarity in substrate compositions, such as shell plus granitic crushed stone and quartz gravel. Even with significant differences between the substrates and water quality, the lengths of the larvae may be similar (PEDREIRA et al., 2009).

The use of quartz gravel and porcelain as a biofilter substrate provided greater larvae growth performance and better water quality. Therefore is recommended its use in water recirculation systems with production of Nile tilapia.

\section{ACKNOWLEDGMENTS}

To FAPEMIG, CAPES, BNB, CNPq for financial support.

\section{REFERENCES}

AL-HAFEDH, Y.S.; ALAM, A.; ALAM, M.A. Performance of plastic biofilter media with different configuration in a water recirculation system for the culture of Nile tilapia (Oreochromis niloticus). Aquacultural Engineering, v.29, n.3-4, p.139-154, 2003.

APHA, AWWA, WEF. Standard Methods for examination of water and wastewater. 22nd ed. Washington: American Public Health Association; 2012, 1360p. 
Rev. Bras. Saúde Prod. Anim., Salvador, v.17, n.3, p.553-560 jul./set., $2016 \quad \underline{\text { http://www.rbspa.ufba.br }}$ ISSN 15199940

BISWAS, A.K.; ENDO, M.;

TAKEUCHI, T. Effect of different

photoperiod cycles on metabolic rate and energy loss of both fed and unfed young tilapia Oreochromis niloticus. Fisheries

Science, v.68, n.3, p.465-477, 2002.

CAHILL, P.L.; HURD, C.L.;

LOKMAN, M. Keeping the water clean

- Seaweed biofiltration outperforms

traditional bacterial biofilms in

recirculating aquaculture. Aquaculture, v.306, n.1-4, p.153-159, 2010.

CARRERA, L.; COTA, N.; MONTES, M., MATEO, E.; SIERRALTA, V.

Broodstock management of the fine flounder Paralichthysads persus

(Steindachner, 1867) using recirculating aquaculture systems. Latino American

Journal of Aquatic Research, v.41, n.1, p.89-98, 2013.

CAVALCANTE JUNIOR, W. Reuso de água em um sistema integrado com peixes, sedimentação, ostras e macroalgas. Revista Brasileira de

Engenharia Agrícola e Ambiental, v.9, n.suplemento, p.118-122, 2000.

CHEN, S.L.; LING, J.; BLANCHETON, J.P. Nitrification kinetics of biofilm as affected by water quality factors. Aquacultural

Engineering, v.34, n.3, p.179-197, 2006.

DAVIDSON, J.; SUMMERFEL, S.T.

Solids removed from a cold water recirculating system -comparison of a swuil separator and radial -flow settler. Aquacultural Engineering, v.33, n.1, p.47-61, 2008.

DUARTE, E.; PEDREIRA, M.M.; SANTOS, A.E.; MOREIRA, F.C.; MOTTA, N.C. Cultivo de pós-larvas de tilápia do Nilo utilizando diferentes proporções de substrato concha/brita no biofiltro. Revista Brasileira de Ciência

Veterinária, v.20, n.1, p.43-48, 2013.

EL-KHALDI, A.T.F. Effect of different stress factors on some physiological parameters of Nile tilapia (Oreochromis niloticus). Saudi Journal of Biological Sciences, v.17, n.3, p.241-246, 2010.

FIA, R.; MATOS, A.T.; MATOS, M.P.; ABREU, E.C.; FIA, F.R.L. Tratamento das águas do processamento dos frutos do cafeeiro em filtro anaeróbio seguido por sistema alagado construído: I - remoção de matéria orgânica. Engenharia

Agrícola, v.30, n.6, p.1.191-1.202, 2010.

FRITZSONS, E.; MONTOVANI, L.E.; CHAVES NETO, A.; HINDI, E.C.

Influência das atividades mineradoras na alteração do $\mathrm{pH}$ e da alcalinidade em águas fluviais: o exemplo do rio Capivari, região do carste paranaense. Engenharia Sanitaria e Ambiental, v.14, n.3, p.381390, 2009.

HOROWITZ, A.; HOROWITZ, S. Improving biofiltration: in recirculating aquaculture systems. Global

Aquaculture Advocate, v.3, n.3, p.7071, 2000.

KUBITZA, F. Sistemas de recirculação: sistemas fechados com tratamento e reuso da água. Panorama da Aquicultura, v.16, n.5, p.15-22, 2006.

KÜÇÜK, S. Effect of different stress factors on some physiological parameters of Nile tilapia (Oreochromis niloticus). African Journal of Biothecnology, v.13, n.14, p.1550-1553, 2014.

LEFEBVRE, S.; BARILLÉ, L.; CLERC, M. Pacific oyster (Crassostrea gigas) feeding responses to a fish-farm effluent. Aquaculture, v.187, n.1-2, p.185-198, 2000. 
Rev. Bras. Saúde Prod. Anim., Salvador, v.17, n.3, p.553-560 jul./set., $2016 \quad \underline{\text { http://www.rbspa.ufba.br }}$ ISSN 15199940

LEKANG, O.I.; KLEPPE, H. Efficiency of nitrification in trickling filters using different filter media. Aquacultural Engineering, v.21, n.3, p.181-199, 2000.

MARTINS, C.I.M.; EDING, E.H.; VERDEGEM, M.C.J.; HEINSBROEK, L.T.N.; SCHNEIDER, O.; BLANCHETON, J.P.; d'ORBCASTEL, E.R.; VERRETH, J.A.J. New developments in recirculating aquaculture systems in Europe: a perspective on environmental sustainability. Aquacultural

Engineering, v.43, n.3, p.83-93, 2010.

OLIVEIRA, J.R.; CARMO, J.L.;

OLIVEIRA, K.K.C.; SOARES, M.C.F. Cloreto de sódio, benzocaína e óleo de cravo-da-índia na água de transporte de tilápia do Nilo. Revista Brasileira de Zootecnia, v.38, n.7, p.1163-1169, 2009.

PAIVA, P.; SILVA, P.C.; BRITO, P.P.; GOMES, J.P.; SILVA, R.F.;

SILVEIRA FILHO, P.R.; ROQUE, R.S. Produção da tilápia tailandesa

Oreochromis niloticus, estocadas em diferentes densidades em tanques-redes de pequeno volume instalados em viveiros de piscicultura povoados ou não com a mesma espécie. Boletim do Instituto de Pesca, v.34, n.1, p.79-88, 2008.

PEDREIRA, M.M.; LUZ, R.K.; SANTOS, J.C.E.; SAMPAIO, E.V.; SILVA, R.S.F. Biofiltração da água em e tipos de substratos na larvicultura de pacamã. Pesquisa Agropecuária

Brasileira, v.44, n.5, p.511-518, 2009.

PEDREIRA, M.M.; RIBEIRO, S.J.

Efeito de um tipo de biofiltro na larvicultura de Pacamã Lophiosilurus alexandri (Siluriformes). Agropecuária Técnica, v.29, n.1-2, p.5-10, 2008.
PEDREIRA, M.M.; MARTINS, M.G.; OTONI, C.J.; DUPIN, A.E.; MOURA, G.S.; FERREIRA, T.A. Biofiltros com diferentes proporções de substratos na larvicultura de piabanha-do-Pardo (Brycon sp.). Zootecnia, v.1, n.1, p.1117, 2014.

SAS. Statistical Analysis System. SAS user's guide: Statistics. Cary: SAS Institute Inc., 1998. 956 p.

SHEINTUCH, M.; TARTAKOVSKY, B.; NARKIS, N.; REBHUN, M.

Substrate inhibition and multiple states in a continuous nitrification process.

Water Resource Research, v.29, n.3, p.953-963, 1995.

SILVA, G.G.H.; CAMARGO, A.F.M.; PONTES, C.S.; MIYASE, L.K.

Características limnológicas da coluna d'água e dos efluentes de viveiros de criação de camarões-da-amazônia.

Revista Brasileira Zootecnia, v.39, n.10, p.2099-2107, 2010.

TANG, X.Q.; HUANG, S.L.; FCIWEM, M.S. Comparsion of phosphorus removal between vertical subsurface flow constructed wetlands with different substrates. Water and Environmental Journal, v.23, n.3, p.180-188, 2009.

WATSON, A.A.; HILL, J.E. Design criteria for recirculating, marine ornamental production system.

Aquacultural Engineering, v.34, n.3, p.157-162, 2006.

Data de recebimento: 28/04/2015

Data de aprovação: 27/06/2016 